\title{
Effects of Landscape Characteristics on Annual Survival of Lesser Prairie-Chickens
}

\author{
SAMANTHA G. ROBINSON ${ }^{1}$ \\ Division of Biology, Kansas State University, Manhattan 66506
}

DAVID A. HAUKOS

U.S. Geological Survey, Kansas Cooperative Fish and Wildlife Research Unit, Manhattan 66506

\author{
REID T. PLUMB, ${ }^{2}$ JOHN D. KRAFT, DANIEL S. SULLINS, JOSEPH M. LAUTENBACH ${ }^{3}$ \\ AND JONATHAN D. LAUTENBACH \\ Division of Biology, Kansas State University, Manhattan 66506
}

BRETT K. SANDERCOCK

Department of Terrestrial Ecology, Norwegian Institute for Nature Research, 7485 Trondheim, Norway

CHRISTIAN A. HAGEN

Department of Fisheries and Wildlife, Oregon State University, Bend 97702

ANNE BARTUSZEVIGE

Playa Lakes Joint Venture, Lafayette, Colorado 80026

AND

\author{
MINDY A. RICE \\ United States Fish and Wildlife Service, National Wildlife Refuge System, Fort Collins, Colorado 80525
}

\begin{abstract}
Aвstract.-Agriculture and development have caused landscape change throughout the southwestern Great Plains in the range of the lesser prairie-chicken (Tympanuchus pallidicinctus). Landscape alteration within the lesser prairie-chicken range may contribute to range contraction and population losses through decreases in survival rates. Our objectives were to determine if: (1) landscape configuration (i.e., the spatial arrangement of habitat) or composition (i.e., the amount of habitat), at the study-site scale, affected annual survival of females, (2) relationships exist between landscape context (i.e., landscape configuration and composition) and weekly survival to assess effects of landscape composition and configuration on lesser prairie-chicken populations, and (3) anthropogenic features influenced daily mortality risk. We captured 170 female lesser prairie-chickens and used very-high-frequency and GPS (Global Positioning System) transmitters to track their movement and survival for 2 y. We used known-fate survival models to test if landscape configuration or composition within three sites in Kansas were related to differences in female survival among sites. In addition we tested for relationships between weekly survival and landscape configuration or composition within home ranges. Finally, we used Andersen-Gill models to test the influence of distance to anthropogenic features on daily mortality risk. Differences in survival were evident between sites with differing landscape compositions as annual survival in Northwestern Kansas $(\hat{S}=$ 0.27 ) was half that of Clark County, Kansas $(\hat{S}=0.56)$, which corresponded with $41.9 \%$ more
\end{abstract}

\footnotetext{
${ }^{1}$ Corresponding author: email: samgr@vt.edu Current address: Department of Fish and Wildlife Conservation, Virginia Tech, 134 Cheatham Hall, 310 W. Campus Dr., Blacksburg, VA, 24061

${ }^{2}$ Current address: California Department of Fish and Wildlife, 1724 Ball Mountain Rd., Montague, CA, 96067

${ }^{3}$ Current address: Wildlife Division, Ohio Department of Natural Resources, Delaware, OH 43015
} 
grassland on the landscape in Clark County; landscape configuration did not measurably differ among sites. Survival was greater for prairie-chickens with home-ranges that had greater patch richness and in areas with 30\% crop and 57\% grassland. Female lesser prairie-chickens also experienced greater mortality risk closer to fences at patch edges. Further conversion of grassland landscapes occupied by lesser prairie-chickens should be avoided to reduce habitat loss and fragmentation thresholds that could affect survival. We suggest continued encouragement of Conservation Reserve Program enrollment in western areas of the lesser prairie-chicken range to maintain or increase the amount of grassland to increase annual survival.

\section{INTRODUCTION}

Settlement of the Southern Great Plains starting in the latter part of the 19th century caused wide-spread alteration of grassland landscapes, which was accelerated following discovery and large-scale utilization of the Ogallala aquifer by the mid-20th century (Lewis, 1990; Coppedge et al., 2001). Landscape fragmentation and habitat loss in the Great Plains, namely loss of grasslands with increasing isolation and reduction in size of grassland patches (Fahrig, 2003), resulted from direct conversion of land from native prairie to agricultural production, including row-cropping or grazing by domestic livestock (Haukos and Boal, 2016; Rodgers, 2016). Quality of remaining grasslands has also declined across time with the alteration of ecological drivers, such as the removal of fire resulting in tree encroachment (Fuhlendorf et al., 2002, 2017; Lautenbach et al., 2016; Spencer et al., 2017). Anthropogenic features on the landscape have further fragmented and isolated grassland patches. Power lines, fences, roads, energy infrastructure, and other types of urbanization can affect distribution and space use of prairie birds, creating barriers to movement, reducing habitat availability due to avoidance, and by enhancing conditions for predators to traverse and perceive the landscape, increasing the risk of predation (Pruett et al., 2009; Hagen et al., 2011). With a growing demand for domestic energy, food, and infrastructure, increases in anthropogenic structures and other landscape changes are persistent, thereby increasing potential negative effects on grassland species (Coppedge et al., 2001; Hovick et al., 2014).

The lesser prairie-chicken (Tympanuchus pallidicinctus) is considered an umbrella species of the western portion of the Southern Great Plains (Miller et al., 2016), and its conservation could provide ecological benefits to many other species (Hagen and Giesen, 2005). Lesser prairie-chickens traverse large areas, requiring a heterogeneous landscape configuration for all life-history stages (Fuhlendorf and Engle, 2001; Haukos and Zavaleta, 2016; Robinson et al., 2017). Population declines of lesser prairie-chickens have been commensurate with aforementioned losses of prairie habitat (Haukos and Zavaleta, 2016). Quantifying demographic responses to variation in available habitat area, habitat configuration, and anthropogenic features on the landscape are necessary to identify factors contributing to population dynamics.

The theoretical foundation underpinning landscape ecology predicts the existence of a threshold of habitat loss, due to reductions in both quantity and quality, that when exceeded is detrimental to demographic rates (Fahrig and Merriam, 1985; Fahrig, 2001, 2003). Population resilience to habitat loss needs to be considered on a species-specific basis, as a species' life-history dictates responses to landscape fragmentation (Dooley and Bowers, 1998). Alternatively, there may be an optimum landscape context that maximizes speciesspecific population growth and therefore persistence. However, if an area supports potential habitat and is colonized by a population, but adult survival or reproductive output of the extant population is not sufficient to offset mortality, long-term persistence is unlikely 
without corresponding immigration (Pulliam, 1988). Relationships between population dynamics and landscape features need to be quantified at multiple scales, from individuals to populations, to assess habitat quality (Fahrig and Merriam, 1985; Dooley and Bowers, 1998; Chalfoun and Martin, 2007). If relationships exist between lesser prairie-chicken adult survival and landscape configuration (i.e., the spatial arrangement of habitat) or composition (i.e., the amount of habitat and patch types), understanding both direct and indirect drivers of these relationships can also assist to target areas on the landscape for conservation planning, development of management strategies, and to assure long-term population persistence (Fahrig, 2002; Mills, 2007; Johnson et al., 2010).

Past studies on lesser prairie-chickens have determined patterns of avoidance of power lines, buildings, and, to a lesser extent, paved roads and oil wells (Hagen et al., 2011; Bartuszevige and Daniels, 2016; Grisham et al., 2016b). Further, increasing landscape fragmentation decreases the probability of lek persistence (Woodward et al., 2001). However, few studies have investigated relationships between landscape context (i.e., landscape configuration and composition) and lesser prairie-chicken survival. At a fine scale, some lesser prairie-chicken populations have increased survival with increased shrub cover and vegetation density (Patten et al., 2005). Habitat loss, increased patch isolation, and anthropogenic development also have the potential to negatively affect female lesser prairiechickens through several mechanisms including both direct mortality (i.e., collision with anthropogenic structures) and indirect mortality (i.e., predator subsidization). Research designed to relate effects of landscape features, composition, and configuration to survival is needed for lesser prairie-chickens. Results of such research will inform future management and conservation actions by identifying whether differences in landscape characteristics are contributing to declines of lesser prairie-chicken populations through effects on annual survival.

Lesser prairie-chickens in Kansas occupy three ecoregions with distinct soil and vegetative characteristics and varying degrees of structural fragmentation (McDonald et al., 2014; Spencer et al., 2017). The existence of populations of lesser prairie-chickens across the Southern Great Plains in differing landscape configurations and compositions allows for a robust assessment of adult survival as a function of landscape characteristics. Our objectives were to: (1) estimate and compare annual lesser prairie-chicken survival among three sites with different landscape contexts, (2) determine relationships between landscape metrics and weekly survival to understand how landscape composition and configuration affect lesser prairie-chicken populations, and (3) estimate the effect of distance to anthropogenic features and landcover type on daily lesser prairie-chicken mortality risk. We hypothesized annual survival would be lower for sites with less available grassland, individuals with less grassland in their home range, and populations with a greater fragmented landcover configuration. We also expected to find anthropogenic features that can act as perches or habitat for predators (power lines, fences, oil wells) would increase the mortality risk for female lesser prairie-chickens.

\section{Methods}

\section{STUDY AREA}

We selected study sites for areas known to have populations of lesser prairie-chickens. Three study sites were located in three ecoregions across the range of lesser prairie-chickens in Kansas (Fig. 1). Ecoregions were characterized by different landscape configuration, soil 


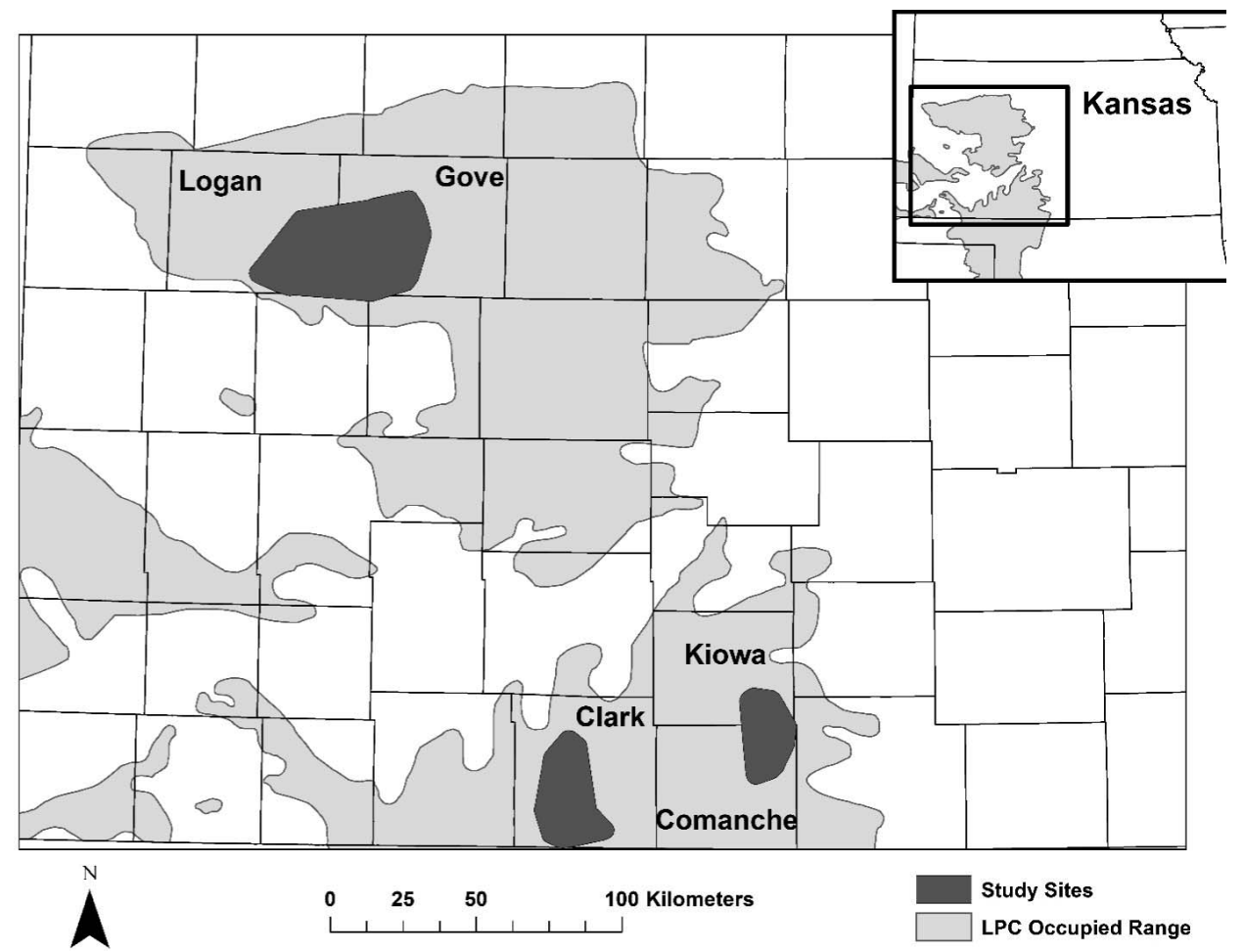

Fig. 1.-Study sites in Kansas used to test the effect of landscape fragmentation on survival of female lesser prairie-chickens during 2013-2015. The underlying gray region represents the current estimated lesser prairie-chicken range within Kansas. Polygons indicate our Northwest Kansas study sites in Gove and Logan counties, our Red Hills study site in Kiowa and Comanche counties, and our Clark site in Clark County, Kansas

types, plant assemblages, management regimes, and vegetation conditions (McDonald et al., 2014; Dahlgren et al., 2016; Haukos et al., 2016; Wolfe et al., 2016).

Our study site in Northwestern Kansas was in the Short-Grass Prairie/Conservation Reserve Program (CRP) Mosaic Ecoregion (McDonald et al., 2014). The Northwestern population of lesser prairie-chickens may have recently expanded north of the Arkansas River (Bain, 2002; Fields et al., 2006; Oyler-McCance et al., 2016; Rodgers, 2016). The Northwestern study area $\left(38^{\circ} 50^{\prime} 15.624^{\prime \prime} \mathrm{N}, 100^{\circ} 46^{\prime} 8.546^{\prime \prime} \mathrm{W}\right)$ was $1714 \mathrm{~km}^{2}$ and located in Gove and Logan counties. The primary land uses in this area were livestock grazing, energy extraction, CRP, and both dryland and row-crop agriculture on silt-loam soils (Table 1).

In southern Kansas lesser prairie-chickens are found in the Mixed-Grass Prairie Ecoregion, with some areas exhibiting vegetation characteristics similar to the Sand Sagebrush Prairie Ecoregion (McDonald et al., 2014). We had two sites in south-central Kansas. The Red Hills study site $\left(37^{\circ} 21^{\prime} 17.102^{\prime \prime} \mathrm{N}, 99^{\circ} 7^{\prime} 13.45^{\prime \prime} \mathrm{W}\right)$ was $491 \mathrm{~km}^{2}$, primarily on private lands in Kiowa and Comanche counties within the Mixed-Grass Prairie Ecoregion. Primary land uses for this area included livestock grazing, oil and gas extraction and exploration, and interspersed row-crop agriculture. The Clark County study site $\left(37^{\circ} 9^{\prime} 34.155^{\prime \prime} \mathrm{N}, 99^{\circ} 52^{\prime} 45.61^{\prime \prime} \mathrm{W}\right)$ within 
TABLE 1.-Composition of grassland, cropland, and Conservation Reserve Program (CRP) and FRAGSTATS metrics calculated within sites for comparison of annual survival of female lesser prairiechickens in Kansas at spatial scale of study sites, study site and surrounding $25 \mathrm{~km}$ radius, and study site and surrounding 50-km radius during 2013-2015

\begin{tabular}{|c|c|c|c|c|c|c|c|}
\hline \multirow[b]{2}{*}{ Site } & \multirow[b]{2}{*}{ Landscape } & \multicolumn{3}{|c|}{ Composition } & \multicolumn{3}{|c|}{ Configuration } \\
\hline & & $\%$ Grassland & \% Crop & $\% \mathrm{CRP}$ & Mean patch size (sE; ha) & Contagion & $\mathrm{IJI}^{1}$ \\
\hline \multirow[t]{3}{*}{ Northwest } & Study Site & 54.0 & 36.0 & 7.4 & $33.29(8.84)$ & 61.5 & 66.5 \\
\hline & $25 \mathrm{~km}$ Buffer & 51.8 & 38.8 & 6.7 & $32.27(8.66)$ & 61.4 & 65.7 \\
\hline & $50 \mathrm{~km}$ Buffer & 40.7 & 51.4 & 4.8 & $27.22(4.26)$ & 61.6 & 61.7 \\
\hline \multirow[t]{3}{*}{ Clark } & Study Site & 76.6 & 14.2 & 5.5 & $50.39(23.34)$ & 69.5 & 58.2 \\
\hline & $25 \mathrm{~km}$ Buffer & 74.2 & 16.4 & 6.0 & $42.99(16.56)$ & 68.0 & 61.8 \\
\hline & $50 \mathrm{~km}$ Buffer & 62.5 & 27.3 & 7.1 & $34.75(9.50)$ & 62.9 & 66.8 \\
\hline \multirow[t]{3}{*}{ Red Hills } & Study Site & 86.7 & 8.9 & 2.2 & $63.49(45.45)$ & 79.3 & 52.4 \\
\hline & $25 \mathrm{~km}$ Buffer & 73.8 & 18.3 & 5.6 & $44.22(22.33)$ & 69.3 & 66.5 \\
\hline & $50 \mathrm{~km}$ Buffer & 60.4 & 31.4 & 5.7 & $35.12(10.03)$ & 63.9 & 66.1 \\
\hline
\end{tabular}

${ }^{1}$ Interspersion/Juxtaposition Index

south-central Kansas was $712 \mathrm{~km}^{2}$ and located on the boundary of the Mixed-Grass Prairie and Sand Sagebrush Prairie Ecoregions. Land use was dominated by livestock grazing, oil and gas extraction, and row-crop agriculture (Table 1).

\section{CAPTURE}

We trapped lesser prairie-chickens at leks in spring (March-May) during 2013 and 2014 using walk-in drift traps and dropnets (Haukos et al., 1990; Silvy et al., 1990; Schroeder and Braun, 1991). Lesser prairie-chickens were identified to sex using the presence of air-sacs, greater pinnae length in males, and tail color patterns (Copelin, 1963).

We fitted female lesser prairie-chickens with either a 12- to 15-g bib-style very-highfrequency (VHF) transmitter (A3960, Advanced Telemetry System, Isanti, MN, U.S.A.) or a rump-mounted 22-g Satellite Platform Transmitting Terminal GPS transmitter (PTT-100, Microwave Telemetry, Columbia, MD, U.S.A.). We attached SAT-PTT transmitters on the rump using leg harnesses made of Teflon ${ }^{\circledast}$ ribbon with elastic at the front of the harness for flexibility (Dzialak et al., 2011). All capture and handling procedures were approved by the Kansas State University Institutional Animal Care and Use Committee (protocol 3241). Field work was conducted under Kansas Department of Wildlife, Parks, and Tourism scientific collection permits (SC-042-2013 and SC-079-2014).

\section{TRACKING}

We located female prairie-chickens outfitted with VHF transmitters via triangulation three to four times per week from March 2013-March 2015. Upon detection individuals were triangulated from three to five points to their estimate location. A three-element hand-held Yagi antenna and receiver were used to take compass bearings on individuals. Bearings were $\geq 15$ degrees apart and taken within 20 min to decrease error from bird movement. Bearings and Universal Transverse Mercator (UTM) positions were entered into the program Location of a Signal (LOAS; Ecological Software Solutions LLC, Hegymagas, Hungary) to estimate the UTM location of the bird and calculate an error polygon around the point. 
Error around VHF locations ranged from 0 to 1 ha. Fixed-wing aircraft were used to locate individuals with VHF radios that had dispersed from the study site.

Birds outfitted with a Satellite-PTT transmitter had up to 10 locations recorded per day between 0600 and 2200 with $18 \mathrm{~m}$ accuracy. Points were uploaded to the Argos satellite system every $3 \mathrm{~d}$ and downloaded weekly for mortality assessments.

\section{SURVIVAL ANALYSIS}

We delineated study site boundaries by creating Minimum Convex Polygons (MCP) using the Minimum Bounding Geometry tool in ArcGIS 10.2 (ESRI Inc., 2013, Redlands, CA, U.S.A.) around all recorded bird points for each field site for the first year of study. We also buffered the study areas at two distances from the centroid of the study area to determine if our study sites were representative of the surrounding landscape and if female survival at the study sites reflected our delineated study sites or the surrounding landscape. We used a 25 $\mathrm{km}$ buffer to standardize study site shape to a circle for a direct comparison among study sites, as $25 \mathrm{~km}$ was the greatest distance from the centroid of any one study area to the outside of the study area MCP; and a $50 \mathrm{~km}$ buffer to represent the overall landscape that lesser prairie-chickens may encounter during dispersal (Earl et al., 2016). Buffers were limited to the current estimated range of the lesser prairie-chicken, as this was the extent of the landcover layer used.

For landscape metrics we used a 2013 landcover layer of the lesser prairie-chicken range developed by Spencer et al. (2017) from $30 \mathrm{~m} \times 30 \mathrm{~m}$ resolution Landsat imagery. The landcover layer included five landcover classes (patch types: grassland, crop, CRP, urban, and water) but grassland and CRP did not distinguish grassland type or structure. Although the $50 \mathrm{~km}$ buffer was limited to the extent of the lesser prairie-chicken range landcover layer, comparison with aerial imagery confirmed the landscape outside of the range was similar to that where the presumed occupied range stops. We merged the landcover layer with the 2014 CRP layer from the U.S. Department of Agriculture, Farm Services Agency, and clipped the landcover layer using the Clip tool in ArcGIS 10.2 to the shape of each study site. We then used program FRAGSTATS to describe landscape configuration within each study site (McGarigal et al., 2012). The contagion metric, interspersion and juxtaposition index (IJI), mean patch size, and standard error of mean patch size were calculated within each study site polygon and for $25 \mathrm{~km}$ and $50 \mathrm{~km}$ buffers around the centroid of the study site as measures of landscape configuration. We used the contagion and IJI metrics as a way to describe the fragmentation within each study site. Contagion is scaled 0 to 100 , where a value of zero equates to a landscape in which there are no like-adjacencies and a value of 100 is a single patch type. Alternatively, the IJI uses the proportion of like-adjacencies on a cell-basis, with a high IJI representing an increasingly fragmented landscape. We also calculated landscape composition of grassland, cropland, and CRP as the percent occurrence of each within the landscape of each study site and 25 and $50 \mathrm{~km}$ buffers around the centroid of each study site (Fig. 2).

To calculate individual covariates for the model testing the effect of landscape characteristics on survival, we created MCPs for all individuals that had $\geq 3$ unique points with error polygons $\leq 1$ ha around each point as an estimate of home range (Table 2). Each bird-year (March 15th-March 14th) was treated as an independent period due to variation in weather and land management across years (e.g., precipitation, application of prescribed fire, haying, crop types, and grazing density). Use of MCPs allow for determination of a single, contiguous landscape potentially available for each individual, as kernel density estimates and Brownian Bridge Movement Models generated for these birds from space-use 


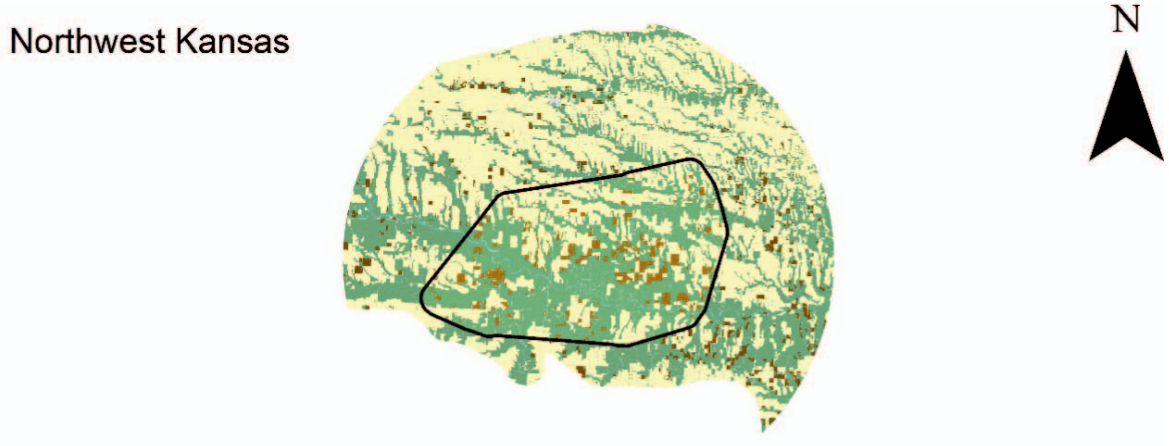

Clark
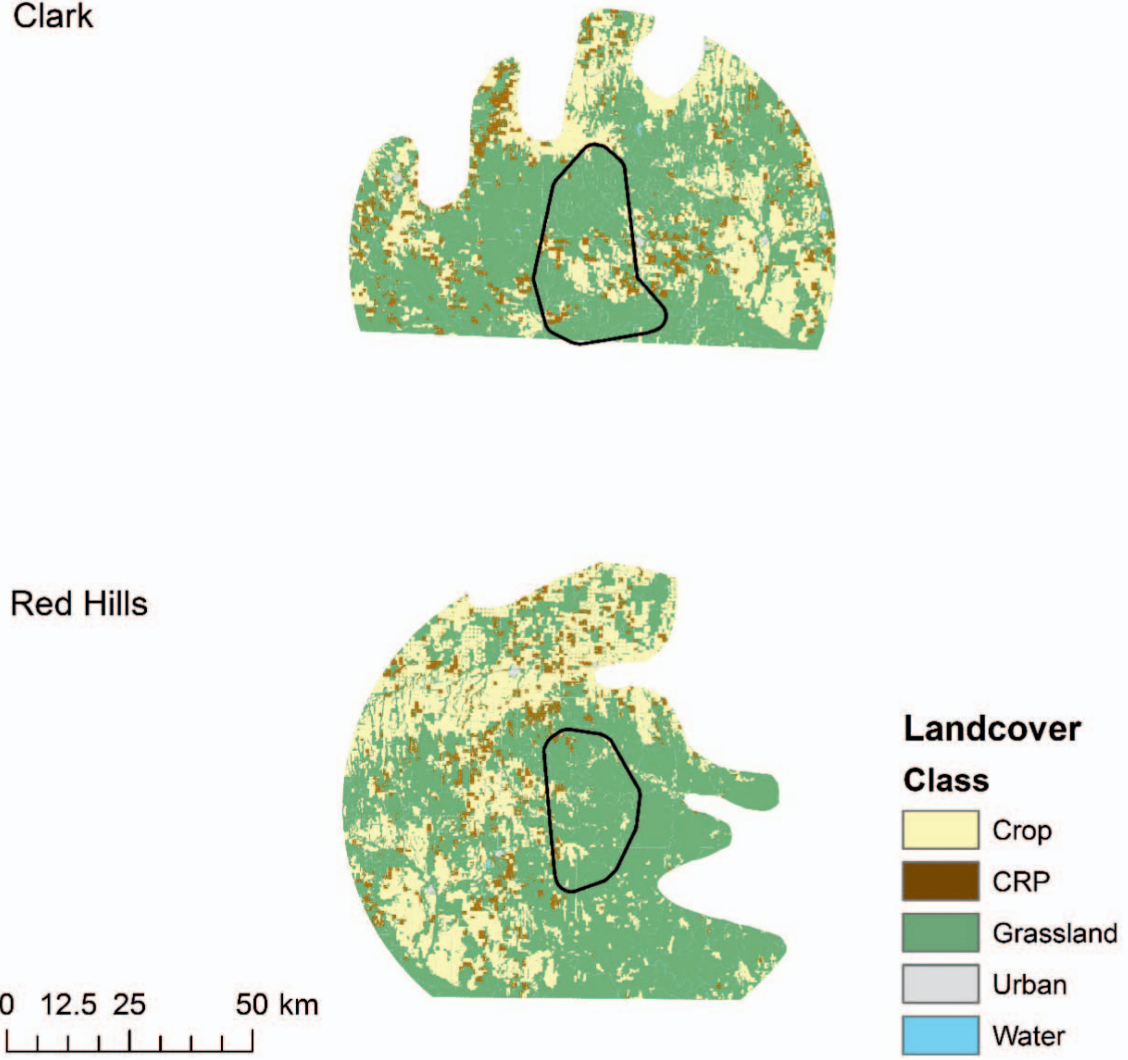

Fig. 2.-Landscape composition of study sites from Northwestern Kansas (Gove and Logan counties; top), Clark (Clark County, Kansas; center), and Red Hills (Kiowa and Comanche counties; bottom), illustrating that study sites have different proportions of landcover types, which differed from the surrounding landscape and represented as a $50 \mathrm{~km}$ buffer from the centroid of the study site 
TABLE 2.-Total available lesser prairie-chicken locations from three Kansas study sites collected using satellite transmitters (SAT-PTT) and very-high-frequency (VHF) transmitters used to calculate minimum convex polygons during 2013-2015. Reported means are the mean of number of points per bird used to calculate the MCP

\begin{tabular}{|c|c|c|c|c|c|c|}
\hline \multirow[b]{2}{*}{ Site } & \multicolumn{3}{|c|}{ SAT-PTT } & \multicolumn{3}{|c|}{ VHF } \\
\hline & $\begin{array}{l}\text { Number of } \\
\text { birds }\end{array}$ & $\begin{array}{l}\text { Total number } \\
\text { of points }\end{array}$ & $\begin{array}{l}\text { Mean points } \\
\text { per bird ( } \mathrm{SE} \text { ) }\end{array}$ & $\begin{array}{l}\text { Number of } \\
\text { birds }\end{array}$ & $\begin{array}{c}\text { Total number } \\
\text { of points }\end{array}$ & $\begin{array}{l}\text { Mean points } \\
\text { per bird ( } \mathrm{SE} \text { ) }\end{array}$ \\
\hline Clark County & 17 & 30,497 & $1,793(246)$ & 7 & 503 & $71(20)$ \\
\hline Northwest & 58 & 78,379 & $1,351(149)$ & 36 & 1,251 & $34(5)$ \\
\hline Red Hills & 31 & 37,740 & $1,217(165)$ & 21 & 1,228 & $58(10)$ \\
\hline
\end{tabular}

analyses were composed of disjointed polygons (Plumb, 2015; Robinson et al., 2017). We used the same landcover data as for the study site analysis, except clipped to the MCP of each bird. Landscape metrics were calculated using FRAGSTATS to measure landscape composition and configuration within the home range of each bird. Patches were truncated at the edge of the MCP, as we were unable to determine a bird's perception of the landscape past where we had location information. Landscape configuration metrics calculated within home ranges were total area, mean patch size, contagion, IJI, and patch richness (McGarigal and Marks, 1995). Patch richness was the number of different patch types within each home range. For landscape composition metrics, we calculated the percentage of each home range that was grassland, cropland, or CRP. We tested for correlation among the configuration metrics using Pearson's correlation coefficient; if a metric pair was correlated at greater than $|\mathrm{r}|=0.5$, we did not include both in the same model.

We used FRAGSTATS metrics of configuration as individual covariates in one model set and FRAGSTATS metrics of composition as individual covariates in a second model set to derive functional relationships (White and Burnham, 1999). We created 14 a priori models using individual FRAGSTATS configuration metrics, additive site and FRAGSTATS metrics, and interactive site and FRAGSTATS metrics, followed by ranking of the models using AIC $_{c}$. We also created 19 a priori models using composition metrics, including study site and quadratic terms.

We used known-fate models in Program MARK to estimate cumulative annual survival for female lesser prairie-chickens at each study site for two bird-years (March 15, 2013-March 14, 2014 and March 15, 2014-March 14, 2015; White and Burnham, 1999). We tested five models, including a null model, a site model, a year model, a site and year additive model, and a site and year interactive model. Models were ranked using Akaike's Information Criterion corrected for small sample size ( $\mathrm{AIC}_{\mathrm{c}}$; Burnham and Anderson, 2002). Models with a $\triangle \mathrm{AIC}_{\mathrm{c}} \leq 2$ were considered competing models. We also modeled weekly survival using the known-fate model in Program MARK to evaluate the effect of landscape characteristics on the survival of individuals (White and Burnham, 1999; Winder et al., 2014b). Encounter histories for both models were compiled using weekly encounters across the 52 wk annual period, although sample sizes varied due to the need for enough points to create MCPs.

\section{ANDERSEN-GILL MODELING}

We used an Andersen-Gill modeling framework to identify how continuous, encounter specific covariates affects mortality risk for lesser prairie-chickens (Dinkins et al., 2014; 
Winder et al., 2017). The mortality risk from Andersen-Gill models is the change in the survival rate with each change in a given covariate (Johnson et al., 2004a). Andersen-Gill models use Cox proportional hazard models, but instead of having an entry date, exit date, and event for each individual, this approach models entry, exit, and event for each encounter per individual (Andersen and Gill, 1982). Use of Andersen-Gill models allows for time periods that individuals were not present in the study, such as dispersal from the study site, transmitter malfunctions, or lack of daily monitoring, such as with VHF individuals. The Andersen-Gill framework also allows for left-censoring of individuals with staggered entry into the data set (Johnson et al., 2004b).

We only used birds that had $\geq 2$ locations, one of which being the mortality location, to model the effect of distance to anthropogenic features on mortality risk. To obtain a covariate for the encounters of each individual bird, we created separate distance rasters of each study site for distance to road, fence, distribution power line, oil well, and known leks using the Euclidean Distance tool in ArcGIS 10.2, with $30 \mathrm{~m} \times 30 \mathrm{~m}$ grid cells. Oil well and road layers were obtained from the Kansas GIS and Data Support Center (http://www. kansasgis.org/). We hand-delineated fences based on field inspection. Distribution power line layers were from the Kansas Corporation Commission (http://www.kcc.state.ks.us/). Each cell of a distance raster layer has a value that identifies the distance that cell is from the nearest structure. For each use-point bird location, we extracted the distance from the starting point of an encounter to each structure using the Extract Multi Values tool in ArcGIS, as well as the landcover type from the landcover and CRP layer. We centered and scaled all input variables (Schielzeth, 2010).

For VHF birds, all available points were used for encounters, as birds were not located more than once on any given day. We randomly selected one point per bird per day for satellite birds as the SAT-PTT birds had as many as 10 points available/day. We chose a point for each day using the r. sample command in Geospatial Modeling Environment to simplify to a daily encounter history and make use of both the SAT-PTT and VHF transmitter points (Beyer, 2015). Only points and mortalities within the delineated study sites were used.

Using the "coxph" function in the "survival" package, we identified the relative effect of covariates on mortality risk and annual survival from regression co-efficients (Therneau, 2014). We built 26 a priori models, which represented each variable alone, additive models of site and variable combinations, and additive models of each combination of two variables. Model diagnostics were tested with the "cox.zph" function to determine if these data met assumptions of proportional hazards (Fox and Weisberg, 2011). All models with $\Delta \mathrm{AIC}_{\mathrm{c}} \leq 2$ were considered competing models. If the mortality risk from the top models differed from zero (i.e., 95\% confidence intervals of the beta estimate did not overlap zero), then we judged the variable to be biologically important and plotted the predicted risk curve.

\section{RESULTS}

STUDY SITE COMPOSITION AND CONFIGURATION

A total of 170 individuals, representing 193 bird years and 108 mortality events were included in the overall model for annual known-fate survival of female lesser prairiechickens, 81 individuals in 2013-2014 and 112 in 2014-2015. There were two top models in the model set with $\Delta \mathrm{AIC}_{\mathrm{c}} \leq 2$, one representing differences among study sites $\left(\mathrm{w}_{\mathrm{i}}=0.59\right)$ and another representing differences among study sites and years $\left(\mathrm{w}_{\mathrm{i}}=0.22\right.$; Table 3$)$. We made inference based on the top-ranked model representing differences among sites, as adding year did not improve the model fit and was considered spurious. Northwest Kansas had a 
TABLE 3.-Comparison of models in Program MARK used to explain variation in annual survival of female lesser prairie-chickens in Kansas for 2013-2014 and 2014-2015. Data from three sites were included in these models; Clark County, Red Hills, and Northwest

\begin{tabular}{lcccc}
\hline \hline \multicolumn{1}{c}{ Model } & $\mathrm{K}^{*}$ & Deviance & $\Delta \mathrm{AIC}_{\mathrm{c}}$ & $w_{i}{ }^{*}$ \\
\hline Site & 3 & 1029.09 & 0.00 & 0.59 \\
Site + Year & 4 & 1029.08 & 2.00 & 0.22 \\
Site $*$ Year & 6 & 1027.70 & 2.62 & 0.16 \\
Constant & 1 & 96.89 & 6.12 & 0.03 \\
Year & 2 & 1036.59 & 7.50 & 0.01 \\
\hline
\end{tabular}

$* \mathrm{~K}=$ Number of parameters, $w_{i}=$ Model weight, AICc of top-ranked model $=1033.09$

lower annual survival estimate than any of the other sites, at $0.27(\mathrm{n}=110,95 \% \mathrm{CI}=0.20-$ 0.38). Survival in Northwestern Kansas was $50 \%$ lower than in Clark County, $(\hat{\mathrm{S}}=0.56, \mathrm{n}=$ $25,95 \% \mathrm{CI}=0.38-0.81$ ). The annual survival of lesser prairie-chickens within the Red Hills was similar to the Clark County site $(\hat{S}=0.48, n=58,95 \%$ CI $=0.36-0.64)$. The overall annual survival of female lesser prairie-chickens across all study sites was $0.37(95 \% \mathrm{CI}=$ $0.30-0.45)$.

Sites differed in landscape configuration and composition metrics (Table 1). Calculated FRAGSTATS contagion metrics within the study sites indicated Northwest Kansas was fragmented relative to the Clark County and Red Hills sites (Table 1). Fragmentation was evident, as contagion values were lower and IJI values were greater for the Northwest site relative to the other study sites. Although high variation among patches resulted in no statistical difference, point estimates of mean patch size were 34 and $47.6 \%$ smaller for the Northwestern site relative to the Clark County and Red Hills sites, respectively. All study sites were less fragmented than their corresponding 25 and $50 \mathrm{~km}$ buffered areas, with larger mean patch sizes and larger contagion values (Table 1).

The Northwest site was composed of less grassland and more cropland than the other study sites (Table 1). It has been hypothesized CRP compensates for the loss of native grassland in the northern portion of the lesser prairie-chicken range, but including CRP as grassland still resulted in the Northwest site supporting 15.2 and 25.3\% less grassland than Clark County or the Red Hills. Additionally, all study sites had more grassland and less cropland in the delineated study areas than the $25 \mathrm{~km}$ or $50 \mathrm{~km}$ buffers (Table 1).

\section{HOME RANGE COMPOSITION AND CONFIGURATION}

We used 170 total bird-years to estimate relationships among weekly survival of lesser prairie-chickens and home-range scale habitat configuration and composition. Home range size was not correlated with the total number of points used to calculate the MCP $(r=0.27)$ and neither home range size nor the number of points used to calculate the MCPs were correlated with configuration metrics within home ranges. The average annual MCP home range size was 3749.43 ha $(\mathrm{SE}=780.02)$. The IJI was negatively correlated with patch richness within home ranges $(\mathrm{r}=-0.52)$; therefore, we only included patch richness as an individual covariate in survival models, as contagion could still be used to assess patch isolation. The sample of individuals for which survival was calculated included 96 mortality events. Only two models had a $\mathrm{w}_{\mathrm{i}}>0$, Site $\times$ Patch Richness $\left(\mathrm{w}_{\mathrm{i}}=0.85, \mathrm{AIC}_{\mathrm{c}}=917.54\right)$ and Site + Patch Richness $\left(\mathrm{w}_{\mathrm{i}}=0.15, \mathrm{AIC}_{\mathrm{c}}=920.96\right)$. The configuration metric model best supported by the data was Site $\times$ Patch Richness, as Site + Patch Richness had a $\triangle$ AICc $>2$. For all sites there 

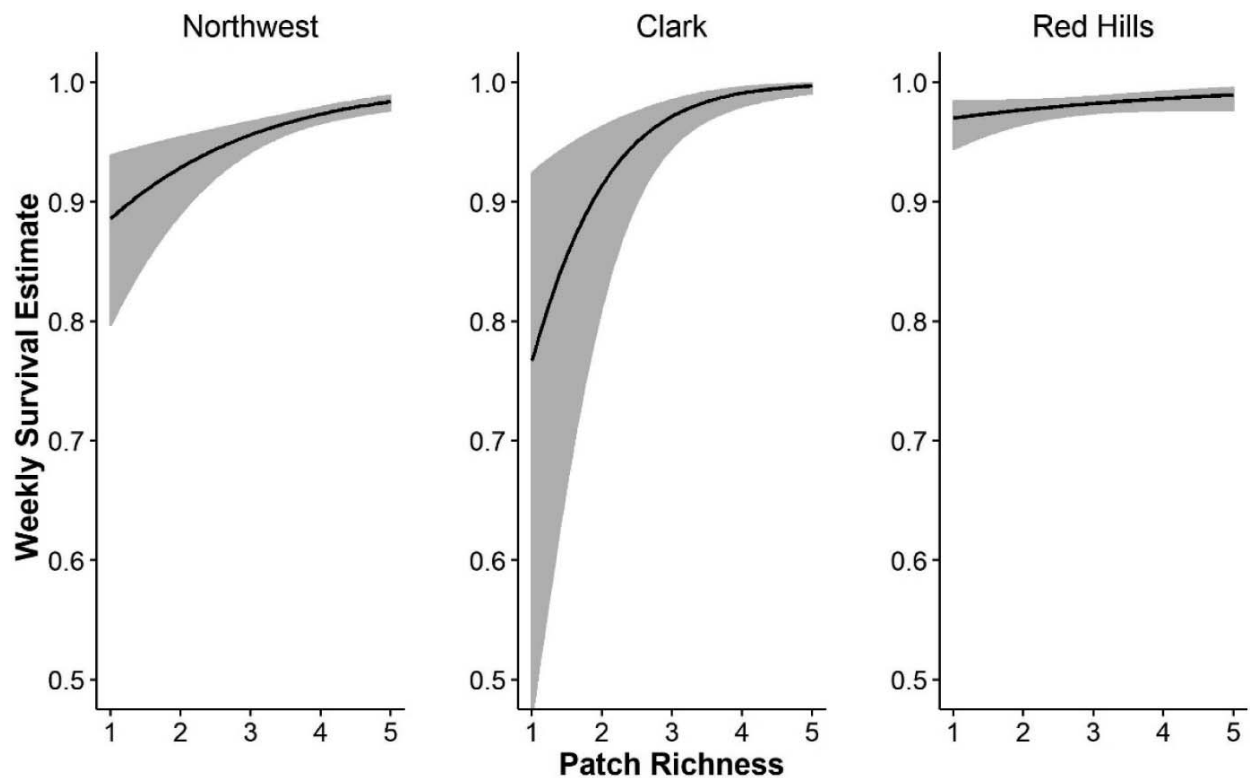

FIG. 3.-Functional relationships from Program MARK for weekly survival of lesser prairie-chickens versus patch richness within individual home ranges in Kansas during 2013-2015. Patch richness is the number of patch types that occurred in each individual home range

was a significant trend of increasing survival as patch richness within home ranges increased $(\beta=1.17,95 \%$ CI $=0.64-1.69$; Fig. 3$)$.

The composition metrics ( $\%$ crop, $\%$ grassland, and \% CRP) were all correlated and therefore were not combined in models. There were two top-ranked models in the home-range composition model set (Table 4). Top-ranked models were Site $+\%$ Crop ${ }^{2}$ and Site $+\%$ Grassland ${ }^{2}$ models. Slope estimates for both models were significant for the linear terms $\left(\beta_{\text {crop }}=0.079,95 \% \mathrm{CI}=0.034-0.13\right.$ and $\beta_{\text {grass }}=0.085,95 \% \mathrm{CI}=0.041-0.13$, respectively) and the quadratic terms $\left(\beta_{\text {crop }^{\wedge} 2}=-0.0013,95 \% \mathrm{CI}=-0.002-0.00025\right.$ and $\beta_{\text {grass } \wedge 2}=-0.00074,95 \% \mathrm{CI}=-0.0011-0.00039$, respectively) indicated a peak in weekly survival when proportion of crop within a lesser prairie-chicken's home range was $31.3 \%$ and proportion of grassland within a lesser prairie-chicken's home range was $57 \%$ (Fig. 4).

\section{ANDERSEN-GILL}

Using one encounter per day for each bird resulted in 18,063 encounters from 189 total bird years with 96 total mortality events. The model best supported by these data was Site + Distance to fence (Table 5). Across all Kansas study sites, mortality risk for female lesser prairie-chickens increased as distance to fence decreased (Fig. 5). Regression coefficients in our model indicate a greater magnitude of risk relative to decreased distance from fences for birds in Northwest Kansas (mortality risk $=1.15$, $\mathrm{sE}=$ 0.38) compared to Red Hills and Clark County (Fig. 5). 
TABLE 4.-Comparison of models in Program MARK used to explain variation in landscape composition on survival of female lesser prairie-chickens in Kansas during 2013-2014 and 2014-2015. Model ranking based on Akaike Information Criterion corrected for small sample size $\left(\mathrm{AIC}_{\mathrm{c}}\right)$ for 19 models, including a null model. Site models considered three study sites: Northwest, Kansas, Red Hills, and Clark County, Kansas. Models with no support $\left(w_{\mathrm{i}}=0\right)$ were not included in these results

\begin{tabular}{lcccc}
\hline \hline \multicolumn{1}{c}{ Model } & $\mathrm{K}^{*}$ & Deviance & $\Delta \mathrm{AIC}_{\mathrm{c}}$ & $w_{\mathrm{i}}^{*}$ \\
\hline Site $+\%$ Crop $^{2}$ & 5 & 920.64 & 0 & 0.36 \\
Site $+\%$ Grass $^{2}$ & 5 & 920.80 & 0.15 & 0.33 \\
Site $*$ Crop & 9 & 915.56 & 2.95 & 0.08 \\
Site $^{2} \%$ Grass $^{2}$ & 9 & 917.61 & 2.99 & 0.08 \\
Site $*$ Crop & 6 & 921.76 & 3.12 & 0.08 \\
Site $+\%$ Crop & 4 & 925.96 & 3.32 & 0.07 \\
\hline
\end{tabular}

$* \mathrm{~K}=$ Number of parameters, $w_{\mathrm{i}}=$ Akaike model weight, $\mathrm{AIC}_{\mathrm{c}}=960.36$ for the best fit model

\section{Discussion}

We investigated effects of landscape composition and configuration on annual survival of female lesser prairie-chickens in Kansas. We were able to identify habitat composition (crop $=31 \%$, grassland $=57 \%$ ) amounts within home ranges to maximize weekly survival and determined that home ranges with greater patch richness had a positive effect on survival. Annual survival varied distinctly among our study sites, and we note the three sites also differed markedly in their landscape composition, suggesting landscape composition influences survival. Increased survival for sites with more grassland cover indicates a minimum threshold grassland area is needed to support a lesser prairie-chicken population, between the levels seen in Northwest Kansas and Clark County (grassland composition 54 to $76 \%$, respectively). Finally, we found mortality risk for lesser prairie-chickens were greatest in Northwest Kansas and increased as distance to fences decreased for all sites.

Results from the individual-level (i.e., home range) analysis were inconclusive in showing that configuration of home ranges have an effect on survival rates. It is possible lesser prairiechickens are already selecting areas for their home range within the range of tolerable fragmentation, which we would be unable to detect with survival models, suggesting lesser prairie-chickens perceive landscape factors outside of their home range. Alternatively, we found proportions of cropland (30\%) and grassland (50-70\%) within home ranges maximizes weekly survival. These results add a survival-based mechanism to past studies that identified occupied lesser prairie-chicken habitat occurred below a threshold of $37 \%$ cultivation and a more recent study indicating abundance and resiliency of lesser prairiechickens decreased after reaching a threshold of 9.6\% cropland (Crawford and Bolen, 1976; Ross et al., 2016a).

We also found a positive significant relationship with an increase in survival corresponding with an increase in patch richness within home ranges. Increasing survival relative to the number of patch types does not necessarily mean increased fragmentation increases survival, as contagion metrics did not explain survival. The patch types themselves could exist in small patches within the grassland matrix, providing additional cover and forage types; therefore, not significantly increasing the breakup of grassland (Campbell, 1972). Instead, this may indicate lesser prairie-chickens experience increased survival when they have a variety of available landcover options within their home range. This relationship is intuitive, as spatial heterogeneity benefits lesser prairie-chickens and other grassland birds, because they require different landscape types throughout different life stages (Fuhlendorf and Engle, 

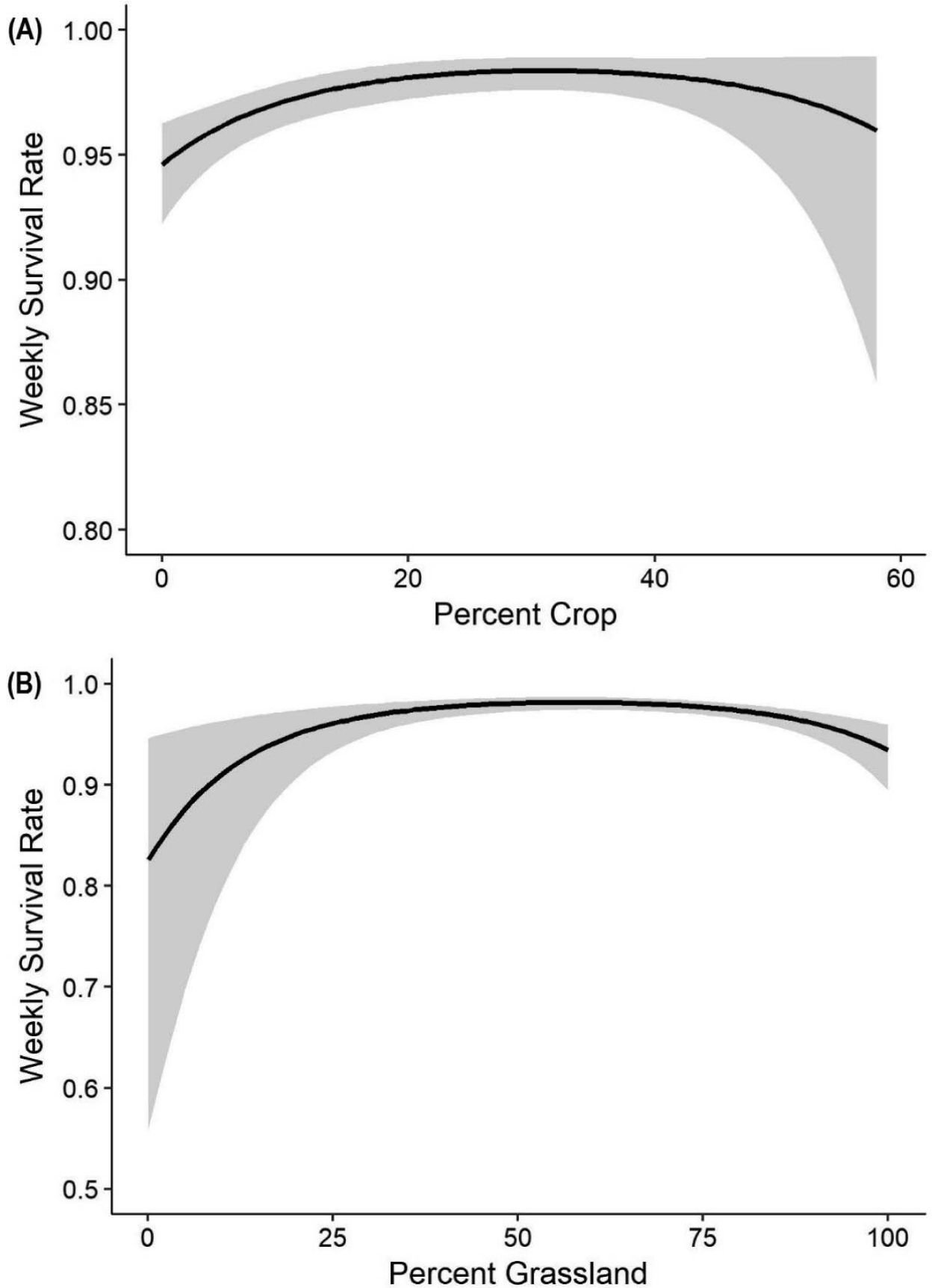

FIG. 4.-Functional relationships from Program MARK for weekly survival of lesser prairie-chickens versus percent crop (A) and percent grassland (B) within individual home ranges during 2013-2015 for three sites in Kansas 
TABLE 5.-Model ranking for Andersen-Gill models, based on Akaike Information Criterion corrected for small sample size $\left(\mathrm{AIC}_{\mathrm{c}}\right.$ ) for 26 models, including a null model, determining the effect of distance to anthropogenic features and landcover type (grassland, cropland, and CRP) on survival of lesser prairiechickens in Kansas during 2013-2015. Models with no support $\left(w_{\mathrm{i}}=0\right)$ were not included in these results

\begin{tabular}{lcccc}
\hline \hline \multicolumn{1}{c}{ Model } & $\mathrm{K}^{*}$ & Deviance & $\Delta$ AICc & $\mathrm{w}_{i}{ }^{*}$ \\
\hline Site + Fence & 3 & 784.44 & 0 & 0.71 \\
Site * Fence & 5 & 782.52 & 2.07 & 0.25 \\
Site + Lek & 3 & 792.44 & 7.99 & 0.01 \\
Site + Oil & 3 & 794.16 & 9.72 & 0.01 \\
\hline
\end{tabular}

$* \mathrm{~K}=$ Number of parameters; AICc $=790.45$ for the best fit model; $\mathrm{w}_{\mathrm{i}}=$ Akaike model weight

2001; Sandercock et al., 2014). Selection for heterogeneity also extends to finer scales, as lesser prairie-chickens select for larger livestock pastures that exhibit greater structural heterogeneity (Kraft, 2016). Effects of habitat loss have been shown to be greater than effects of fragmentation for species abundance, species persistence, and reproduction (Andrén, 1994; Fahrig, 2003). A single female lesser prairie-chicken can require thousands of hectares of space during her annual cycle, most of which should be grasslands (Robinson et al., 2017). Therefore, our data suggests lesser prairie-chickens may exhibit enough mobility to navigate among the various patches to find the requisite types of grassland for distinct life stages (i.e., nesting, brooding, foraging, Hagen et al., 2009).

Our survival estimates in Northwest Kansas were lower than any other published estimates of annual lesser prairie-chicken survival, which range from 0.31 to 0.59 , although estimates from Red Hills and Clark County sites fall within the published range (Jamison, 2000; Hagen et al., 2007; Lyons et al., 2009; Haukos and Zavaleta, 2016). Differences among the study sites, with the Northwest site being more fragmented at the patch and cell level and also comprised of less grassland, were evident at the study-site scale and within $25 \mathrm{~km}$ and $50 \mathrm{~km}$ buffered landscapes. While differences among sites in proportion of landcover type may not necessarily mean habitat loss in all landscapes, the Southern Great Plains region was nearly all grass or shrub-dominated prairie before the arrival of European settlers and onset of agriculture (Samson and Knopf, 1994). One of our most pronounced findings was that all of the study sites, which were chosen due to their recognized densities of lesser prairiechickens, were less fragmented and comprised of more grassland than the surrounding landscape out to a $50 \mathrm{~km}$ buffer. This suggests aggressive restoration efforts may be necessary to restore grassland at broader scales and reduce fragmentation to increase the probability of lesser prairie-chicken survival within their occupied range.

The effect of distance to anthropogenic features on annual survival indicated the closer an individual was to a fence, the greater risk of mortality, and the risk varied regionally. Fence collision risk has been shown to be significant in Oklahoma (Wolfe et al., 2007). However, increased mortality risk relative to fences in our study was unlikely to be attributed to collision mortality as in a concurrent study Robinson et al. (2016) reported evidence for only one collision/187 km of fence surveyed despite walking $>2800 \mathrm{~km}$ of fences and documenting one mortality for 12,706 documented fence crossings by transmittered lesser prairie-chickens. Instead of collision risk, the increased mortality risk in relation to fences in Kansas could be due to a relationship with increasing predator densities at patch edges. Fences are frequently used as perches by raptors, one of the most common lesser prairiechicken predators (Hagen et al., 2007; Behney et al., 2012; Boal, 2016). Fences also serve as corridors for mammalian predators, such as coyotes (Canis latrans) or red fox (Vulpes vulpes), 


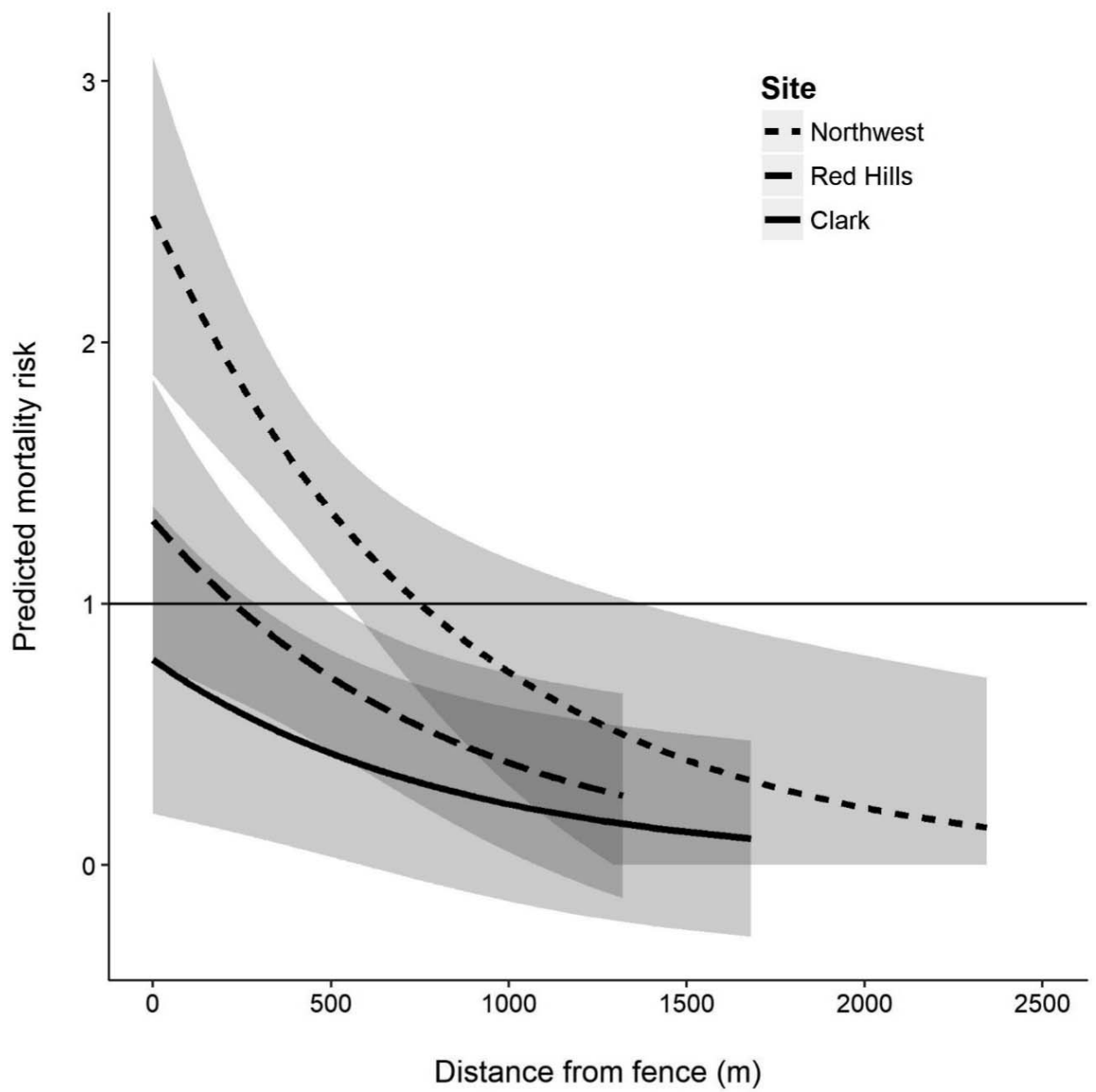

FIG. 5.-Predicted mortality risk of female lesser prairie-chickens for distance to fence from AndersenGill models for continuous encounter covariates during 2013-2015. Site + distance to fence (m) predicted curve, with three different study sites in Kansas (Clark County, Red Hills, and Northwest). Predicted curves only represent mortality risk for distance to fence that we located mortalities. Mortality risk from this model indicate that lesser prairie-chickens in Northwest Kansas experience greater risk (mortality risk at distance $0=2.49,95 \% \mathrm{CI}=1.88-3.09$ ) in relation to fences than lesser prairie-chicken in the Red Hills (mortality risk at distance $0=1.32,95 \% \mathrm{CI}=0.78-1.86$ ) and Clark County (mortality risk at distance $0=0.79,95 \% \mathrm{CI}=0.20-1.37)$ study sites

that are known predators of grassland birds. Increase of predation risk is especially relevant in working grasslands where two-track roads tend to coincide with fences, which can act as mammalian movement corridors (Bradley and Fagre, 1988). Our analysis indicated distance to powerline, oil well, or road had little influence on lesser prairie-chicken mortality risk, contrary to Hovick et al. (2014) reporting these anthropogenic features negatively affected survival and lek persistence for other grouse species. Lesser and greater prairie-chickens 
(Tympanuchus cupido) have already been shown to exhibit avoidance behavior of anthropogenic features such as power lines (Hagen et al., 2011) and wind turbines (Winder et al., 2014a); therefore, if avoidance has already occurred, detection of an effect on survival may be difficult.

Combining evidence from all three sets of survival estimation, lesser prairie-chickens in Northwestern Kansas are likely to experience lower survival in the long-term relative to the other study sites in Kansas, due to greater mortality risk. The percentage of grassland in Northwest Kansas (54\%) may be near the threshold for persistence of lesser prairie-chickens. Prior to the establishment of the CRP in Kansas, lesser prairie-chickens were not detected in Northwestern Kansas (Rodgers, 2016). Properties enrolled in the CRP generally replaced cropland, as prior to CRP many landscapes exceeded the cropland threshold for persistence of lesser prairie-chickens. Grasses in CRP grasslands also contribute structural heterogeneity to the short-grass prairie landscape (Kraft, 2016; Spencer et al., 2017). Without continued support and enrollment of land into CRP, the landscape currently supporting lesser prairiechickens in Northwestern Kansas could easily dip below the threshold level of grassland and negatively affect annual survival and population growth rates.

Although we were able to identify a home range landcover composition that increased annual survival, the optimum cropland composition was exceeded within the Northwest study site and $25 \mathrm{~km}$ and $50 \mathrm{~km}$ buffers. Therefore, it is less likely for birds to have the ability to place their home ranges in areas to reach this optimum composition in the Northwest population, which could have contributed to the relatively low annual survival. Furthermore, our conclusions are based on a landcover layer that does not distinguish grassland structure appropriate for lesser prairiechickens (i.e., mixed-grass prairie compared to short-grass prairie: Spencer et al., 2017). We may have overestimated the amount of grassland available for lesser prairie-chickens in the western, more arid, portion of the species range by including short-grass prairie, where grassland management can leave grassland unsuitable for lesser prairie-chickens (Hagen et al., 2004). Consideration of available grassland structure and reduced grassland area at buffers surrounding our study areas could lead to less available habitat within these ecoregions than we presumed, such that if birds disperse from the immediate study area, they would have little chance of finding available habitat resulting in an increased likelihood of succumbing to mortality (Earl et al., 2016; D. Haukos, unpubl. data).

Our study was partially conducted during and following a period of severe drought (2012 and 2013), which has been linked to lesser prairie-chicken declines (Ross et al., 2016b). The drought could have depressed survival rates if structure of residual vegetation was insufficient to provide concealment from predators (Ross et al., 2016b). Across all sites and years, the majority of mortality events occurred during the nesting season, before the growing season for warm-season grasses (Plumb, 2015; Robinson, 2015). The lack of residual vegetation during drought could have left female lesser prairie-chickens at all sites more exposed on their nests (Hagen and Giesen, 2005; Grisham et al., 2016a), but the northwest portion of the lesser prairie-chicken range in Kansas is more arid than the south-central sites; therefore, the effect of drought could have exacerbated mortality and further explain lower survival in this region during our study (Robinson et al., 2017). Additionally, the increase of survival with an increasing number of patch types could link to drought, as lesser prairie-chickens may seek out CRP for the increased cover (Spencer et al., 2017) and cropland for foraging opportunities (Campbell, 1972).

Given our results, managers interested in benefiting lesser prairie-chicken populations and increasing their resiliency to intensive drought could maintain grassland within the core occupied lesser prairie-chicken range and restore croplands adjacent to grasslands. Spatial 
heterogeneity of conserved grassland would increase occupancy and available habitat for required life stages (Hagen et al., 2009, 2016). Additionally, to increase the occupied range of the lesser prairie-chicken, the amount of grassland in landscapes outside of the areas where lesser prairie-chickens currently persist needs to be increased to surpass the 50-70\% threshold, within an average lesser prairie-chicken home range, to improve survival. Dispersal may be facilitated by restoring grassland close to existing lesser prairie-chicken populations to increase the probability of range expansion (Earl et al., 2016). If grasslands are reduced below the threshold of landscape composition required for lesser prairiechickens, we could see declines in adult female survivorship. Increased CRP enrollment may supplement native grassland, especially within the short-grass prairie (Hagen et al., 2016), and targeted enrollment should occur close to existing lesser prairie-chicken populations and in close proximity to grassland to increase the likelihood of population persistence. Future research would benefit by investigating landscape connectivity and the ability of birds to disperse though different landscape configurations to prioritize areas for grassland conservation and management.

Acknowledgments. -We thankJ. Pitman, K. Sexton, J. Kramer, M. Mitchener, D. Dahlgren, J. Prendergast, C. Berens, G. Kramos, A. Flanders, and S. Hyberg for their assistance with the project. Research was funded by the Federal Aid in Wildlife Restoration Grant W-73-R; US Geological Survey; US Dept of Agriculture (USDA), Natural Resources Conservation Service, Lesser Prairie-Chicken Initiative; Kansas Wildlife, Parks, and Tourism (Federal Assistance Grant KS W-73-R-3); USDA Farm Services CRP Monitoring, Assessment, and Evaluation (12-IA-MRE CRP TA\#7, KSCFWRU RWO 62). We also thank two anonymous reviewers for reviewing earlier versions of this manuscript. Any use of trade, firm, or product names is for descriptive purposes only and does not imply endorsement by the U.S. Government.

\section{Literature Cited}

Andersen, P. K. and R. D. GiLl. 1982. Cox's regression model for counting processes: a large sample study. Ann. Stat., 10:1100-1120.

ANDRÉn, H. 1994. Effects of habitat fragmentation on birds and mammals in landscapes with different proportions of suitable habitat: a review. Oikos, 71:355-366.

BaIN, M. R. 2002. Male-male competition and mating success on leks attended by hybrid prairie-chicken. Thesis, Fort Hays State University, Hays, Kan.

Bartuszevige, A. M. and A. Daniels. 2016. Impacts of energy development, anthropogenic structures, and land use change on lesser prairie-chickens. p. 205-220. In: D. A. Haukos and C. W. Boal (eds.). Ecology and conservation of lesser prairie-chickens. CRC Press, Boca Raton, Fla.

Behney, A. C., C. W. Boal, H. A. Whitlaw, and D. R. Lucia. 2012. Raptor community composition in the Texas southern high plains lesser prairie-chicken range. Wildl. Soc. Bull., 36:291-296.

Beyer, H. L. 2015. Geospatial Modelling Environment (version 0.7.2.0). http://spatialecology.com/gme. Accessed 15 Sep 2015.

BoAL, C. W. 2016. Predation and lesser prairie-chickens. p. 145-158. In: D. A. Haukos and C. W. Boal (eds.). Ecology and conservation of lesser prairie-chickens. CRC Press, Boca Raton, Fla.

Bradley, L. C. and D. B. Fagre. 1988. Coyote and bobcat responses to integrated ranch management practices in south Texas. J. Range Manag., 41:322-327.

Burnham, K. P. and D. R. Anderson. 2002. Model selection and multimodel inference, 2nd ed. Springer, N.Y., USA.

CAmpbell, H. 1972. A population study of lesser prairie chickens in New Mexico.J. Wildl. Manage., 36:689-699.

Chalfoun, A. D. and T. E. Martin. 2007. Assessments of habitat preferences and quality depend on spatial scale and metrics of fitness. J. Appl. Ecol., 44:983-992.

Copelin, F. F. 1963. The lesser prairie chicken in Oklahoma. Technical bulletin, No. 6., Oklahoma Department of Wildlife Conservation, Oklahoma City, Okla. 
Coppedge, B. R., D. M. Engle, R. E. Masters, and M. S. Gregory. 2001. Avian response to landscape change in fragmented Southern Great Plains grasslands. Ecol. Appl., 11:47-59.

Crawford, J. A. and E. G. Bolen. 1976. Effects of land use on lesser prairie chickens in Texas. J. Wildl. Manage, 40:96-104.

Dahlgren, D. K., R. D. Rogers, R. D. Elmore, and M. R. Bain. 2016. Grasslands of western Kansas, north of the Arkansas River. p. 259-280. In: D. A. Haukos and C. W. Boal (eds.). Ecology and conservation of lesser prairie-chickens. CRC Press, Boca Raton, Fla.

Dinkins, J. B., M. R. Conover, C. P. Kirol, J. L. Beck, and S. N. Frey. 2014. Greater Sage-Grouse (Centrocercus urophasianus) hen survival: effects of raptors, anthropogenic and landscape features, and hen behavior. Can. J. Zool., 92:319-330.

Dooley, J. L. And M. A. Bowers. 1998. Demographic responses to habitat fragmentation: experimental tests at the landscape and patch scale. Ecology, 79:969-980.

Dzialak, M. R., C. V. Olson, S. M. Harju, S. L. Webb, J. P. Mudd, J. B. Winstead, and L. D. Hayden-Wing. 2011. Identifying and prioritizing greater sage-grouse nesting and brood-rearing habitat for conservation in human-modified landscapes. PLoS One, 6:1-19.

Earl, J. E., S. D. Fuhlendorf, D. A. Haukos, A. M. Tanner, R. D. Elmore, and S. A. Carleton. 2016. Characteristics of lesser prairie-chicken (Tympanuchus pallidicinctus) long-distance movements across their distribution. Ecosphere, 7:1-13.

FAHRIG, L. 2001. How much habitat is enough? Biol. Conserv., 100:65-74.

2002. Effect of habitat fragmentation on the extinction threshold: a synthesis. Ecol. Appl., 12:346-353.

2003. Effects of habitat fragmentation on biodiversity. Annu. Rev. Ecol. Syst., 34:487-515.

and G. Merriam. 1985. Habitat patch connectivity and population survival. Ecology, 66:1762-1768.

Fields, T. L., G. C. White, W. C. Gilgert, and R. D. Rodgers. 2006. Nest and brood survival of lesser prairie-chickens in west central Kansas. J. Wildl. Manage., 70:931-938.

Fox, J. AND S. WEISBERG. 2011. Cox proportional-hazards regression for survival data in R. p. 1-20. In: An appendix to an R Companion to Applied Regression, 2nd ed. SAGE, Washington, D.C.

Funlendorf, S. D. And D. M. Engle. 2001. Restoring heterogeneity on rangelands: ecosystem management based on evolutionary grazing patterns. Bioscience, 51:625-632.

—, T. J. Hovick, R. D. Elmore, A. M. Tanner, D. M. Engle, and C. A. Davis. 2017. A hierarchical perspective to woody plant encroachment for conservation of prairie-chickens. Rangel. Ecol. Manag., 70:9-14.

— A. J. W. Woodward, D. M. Leslie, And J. S. Shackford. 2002. Multi-scale effects of habitat loss and fragmentation on Lesser Prairie-Chicken populations of the US Southern Great Plains. Landsc. Ecol., 17:617-628.

Grisham, B. A., A. J. Godar, C. W. Boal, and D. A. Haukos. 2016a. Interactive effects between nest microclimate and nest vegetation structure confirm microclimate thresholds for Lesser PrairieChicken nest survival. Condor, 118:728-746.

- J. C. Zavaleta, A. C. Behney, P. K. Borsdorf, D. R. Lucia, C. W. Boal, and D. A. Haukos. 2016b. Ecology and conservation of lesser prairie-chickens in sand shinnery oak prairies. p. 315-344. In: D.A. Haukos and C.W. Boal (eds.). Ecology and conservation of lesser prairie-chickens. CRC Press, Boca Raton, Fla.

Hagen, C. A. And K. M. Giesen. 2005. Lesser Prairie-Chicken. https://birdsna.org/Species- Account/ bna/species/lepchi. Accessed 12 Dec 2013.

Hagen, C. A., B. E. Jamison, K. M. Giesen, and T. Z. Riley. 2004. Guidelines for managing lesser prairiechicken populations and their habitats. Wildl. Soc. Bull., 32:69-82.

D. C. Pavlacky, K. Adachi, F. E. Hornsby, T. J. Rintz, and L. L. McDonald. 2016. Multiscale occupancy modeling provides insights into range-wide conservation needs of Lesser PrairieChicken (Tympanuchus pallidicinctus) . Condor, 118:597-612.

— J. J. Pitman, T. M. Loughin, B. K. Sandercock, R. J. Robel, and R. D. Applegate. 2011. Impacts of anthropogenic features on habitat use by lesser prairie-chickens. p. 63-76. In: Ecology, conservation, and management of grouse. University of California Press, Los Angeles. 
Hagen, C. A., J. C. Pitman, B. K. Sandercock, R. J. Robel, and R. D. Applegate. 2007. Age-specific survival and probable causes of mortality in female lesser prairie-chickens. J. Wildl. Manage., 71:518-525. B. K. Sandercock, J. C. Pitman, R. J. Robel, and R. D. Applegate. 2009. Spatial variation in lesser prairie-chicken demography: a sensitivity analysis of population dynamics and management alternatives. J. Wildl. Manage., 73:1325-1332.

Haukos, D. A. and C. W. Boal. 2016. Ecology and conservation of lesser prairie-chickens. D. A. Haukos and C. W. Boal (eds.). CRC Press, Boca Raton, Fla. 25-26 p.

- A. A. Flanders, C. A. Hagen, and J. C. Pitman. 2016. Lesser prairie-chickens of the sand sagebrush prairie. p. 299-314. In: D. A. Haukos and C. W. Boal (eds.). Ecology and conservation of lesser prairie-chickens. CRC Press, Boca Raton, Fla.

- L. M. Smith, and G. S. Broda. 1990. Spring trapping of lesser prairie-chickens. J. F. Ornithol., 61:20-25.

and J. C. Zavaleta. 2016. Habitat. p. 99-132. In: D. A. Haukos and C. W. Boal (eds.). Ecology and conservation of lesser prairie-chickens. CRC Press, Boca Raton, Fla.

Hovick, T. J., R. D. Elmore, D. K. Dahlgren, S. D. Fuhlendorf, and D. M. Engle. 2014. Evidence of negative effects of anthropogenic structures on wildlife: a review of grouse survival and behaviour. J. Appl. Ecol., 51:1680-1689.

Jamison, B. E. 2000. Lesser prairie-chicken chick survival, adult survival, and habitat selection and movements of males in fragmented rangelands of southwestern Kansas. Thesis, Kansas State University, Manhattan, Kans.

Johnson, C. J., M. S. Boyce, C. C. Schwartz, and M. A. Haroldson. 2004a. Modeling survival: application of the Andersen-Gill model to Yellowstone grizzly bears. J. Wildl. Manage., 68:966-978.

D. R. SEIP, AND M. S. Boyce. 2004b. A quantitative approach to conservation planning: using resource selection functions to map the distribution of mountain caribou at multiple spatial scales. J. Appl. Ecol., 41:238-251.

Johnson, H. E., L. S. Mills, T. R. Stephenson, and J. D. Wehausen. 2010. Population-specific vital rate contributions influence management of an endangered ungulate. Ecol. Appl., 20:1753-1765.

KrAFT, J. D. 2016. Vegetation characteristics and lesser prairie-chicken responses to land cover types and grazing management in western Kansas. Thesis, Kansas State University, Manhattan.

Lautenbach, J. M., R. T. Plumb, S. G. Robinson, C. A. Hagen, D. A. Haukos, and J. C. Pitman. 2016. Lesser prairie-chicken avoidance of trees in a grassland landscape. Rangel. Ecol. Manag., 70:78-86.

LEWIS, J. 1990. The Ogallala Aquifer: an underground sea. EPA J., 16:42-44.

Lyons, E. K., B. A. Collier, N. J. Silvy, R. R. Lopez, B. E. Toole, R. S. Jones, and S. J. DeMaso. 2009. Breeding and non-breeding survival of lesser prairie-chickens Tympanuchus pallidicinctus in Texas, USA. Wildlife Biol., 15:89-96.

McDonald, L., G. Beauprez, G. Gardner, J. Griswold, C. Hagen, F. Hornsby, D. Klute, S. Kyle, J. Pitman, T. Rintz, D. Schoeling, and B. Van Pelt. 2014. Range-wide population size of the lesser prairiechicken: 2012 and 2013. Wildl. Soc. Bull., 38:536-546.

McGarigal, K., S. A. Cushman, and E. Ene. 2012. FRAGSTATS v4: Spatial Pattern Analysis Program for Categorical and Continuous Maps. Computer software program produced by the authors at the University of Massachusetts, Amherst.

McGarigal, K. And B. J. Marks. 1995. Spatial pattern analysis program for quantifying landscape structure. Gen. Tech. Rep. PNW-GTR-351.

Miller, R. F., D. E. Naugle, J. D. Maestas, C. A. Hagen, and G. Hall. 2016. Special issue: targeted woodland removal to recover at-risk grouse and their sagebrush-steppe and prairie ecosystems. Rangel. Ecol. Manag., 70:1-8.

Mills, L. S. 2007. Conservation of wildlife populations: demography, genetics and movement. WileyBlackwell, Hoboken, N.J.

Oyler-McCance, S. J., R. W. DeYoung, J. A. Fike, C. A. Hagen, J. A. Johnson, L. C. Larsson and M. A. PAtTEn. 2016. Rangewide genetic analysis of lesser prairie-chicken reveals population structure, range expansion, and possible introgression. Conserv. Genet., 17:643-660. Springer, Netherlands. 
Patten, M. A., D. H. Wolfe, E. Shochat, and S. K. Sherrod. 2005. Effects of microhabitat and microclimate selection on adult survivorship of the lesser prairie-chicken. J. Wildl. Manage., 69:1270-1278.

PLumb, R. T. 2015. Lesser prairie-chicken movement, space use, survival and response to anthropogenic structures in Kansas and Colorado. Thesis, Kansas State University, Manhattan.

Pruett, C. L., M. A. Patten, And D. H. Wolfe. 2009. Avoidance behavior by prairie grouse: implications for development of wind energy. Conserv. Biol., 23:1253-1259.

Pulliam, H. R. 1988. Sources, sinks, and population regulation. Am. Nat., 132:652-661.

Robinson, S. G. 2015. Landscape ecology, survival and space use of lesser prairie-chickens. Thesis, Kansas State University, Manhattan.

, D. A. Haukos, R. T. Plumb, C. A. Hagen, J. C. Pitman, J. M. Lautenbach, D. S. Sullins, J. D. Kraft, and J. D. Lautenbach. 2016. Lesser prairie-chicken fence collision risk across its northern distribution. J. Wildl. Manage., 80:906-915.

, J. M. Lautenbach, D. S. Sullins, J. D. Kraft, J. D. Lautenbach, C. A. Hagen, and J. C. Pitman. 2017. Nonbreeding home-range size and survival of lesser prairie-chickens. J. Wildl. Manage., doi: 10.1002/jwmg.21390.

RodGers, R. D. 2016. A history of lesser prairie-chickens. p. 15-38. In: D. A. Haukos and C. W. Boal (eds.). Ecology and conservation of lesser prairie-chickens. CRC Press, Boca Raton, Fla.

Ross, B. E., D. A. Haukos, C. A. Hagen, and J. C. Pitman. 2016a. Landscape composition creates a threshold influencing lesser prairie-chicken population resilience to extreme drought. Glob. Ecol. Conserv., 6:179-188.

- D. Haukos, C. Hagen and J. Pitman. 2016b. The relative contribution of climate to changes in lesser prairie-chicken abundance. Ecosphere, 7:e01323. doi: 10.1002/ecs2.1323.

Ross, B. E., D. A. Haukos, C. A. Hagen, And J. Pitman. 2018. Combining multiple sources of data to inform conservation of lesser prairie-chicken populations. Auk, 135:228-239.

Samson, F. and F. Knopf. 1994. Prairie conservation in North America. Bioscience, 44:418-421.

Sandercock, B. K., M. Alfaro-Barrios, A. E. Casey, T. N. Johnson, T. W. Mong, K. J. Odom, K. M. Strum, V. L. Winder, J. T. N., T. W. Mong, K. J. Odom, K. M. Strum, and V. L. Winder. 2014. Effects of grazing and prescribed fire on resource selection and nest survival of upland sandpipers in an experimental landscape. Landsc. Ecol., 30:325-337.

Schielzeth, H. 2010. Simple means to improve the interpretability ofregression co-efficients. Methods Ecol. Evol., 1:103-113.

Schroeder, M. A. and C. E. Braun. 1991. Walk-in traps for capturing greater prairie-chickens on leks. J. F. Ornithol., 62:378-385.

Silvy, N. J., M. E. Morrow, E. J. Shanley, and R. D. Slack. 1990. An improved drop net for capturing wildlife. Proc. Annu. Conf. Southeast. Assoc. Fish Wildl. Agencies, 44:374-378.

Spencer, D., D. Haukos, C. Hagen, M. Daniels, and D. Goodin. 2017. Conservation Reserve Program mitigates grassland loss in the lesser prairie-chicken range of Kansas. Glob. Ecol. Conserv., 9:2138.

TherneAu, T. M. 2014. A Package for Survival Analysis in S. version 2.38, http://CRAN.R-project.org/ package $=$ survival.

White, G. C. And K. P. Burnham. 1999. Program MARK: survival estimation from populations of marked animals. Bird Study, 46:S120-S139.

Winder, V. L., L. B. Mcnew, A. J. Gregory, L. M. Hunt, S. M. Wisely, and B. K. SANDERcock. 2014a. Effects of wind energy development on survival of female greater prairie-chickens. J. Appl. Ecol., 51:395-405.

Winder, V. L., L. B. McNew, A. J. Gregory, L. M. Hunt, S. M. Wisely, and B. K. Sandercock. 2014b. Space use by female greater prairie-chickens in response to wind energy development. Ecosphere, 5:art3. doi: 10.1890/ES13-00206.1

Winder, V. L., L. B. Mcnew, J. C. Pitman, and B. K. Sandercock. 2017. Effects of rangeland management on survival of female greater prairie-chickens. J. Wildl. Manage., 51:395-405.

Wolfe, D. H., L. C. Larsson, and M. A. Patten. 2016. The lesser prairie-chicken in the mixed-grass prairie of Oklahoma, Kansas and Texas. p. 299-314. In: Ecology and conservation of lesser prairiechickens. CRC Press, Boca Raton, Fla. 
M. A. Patten, E. Shochat, C. L. Pruett, and S. K. Sherrod. 2007. Causes and patterns of mortality in lesser prairie-chickens Tympanuchus pallidicinctus and implications for management. Wildlife Biol., 13:95-104.

Woodward, A. J. W., S. D. Fuhlendorf, D. M. Leslie, and J. Shackford. 2001. Influence of landscape composition and change on lesser prairie-chicken (Tympanuchus pallidicinctus) populations. Am. Midl. Nat., 145:261-274.

Submitted 4 December 2017

ACCEPTED 1 March 2018 